\title{
Integrating research into practice
}

\author{
Jonathan D. Eldredge, MLS, PhD, AHIP
}

See end of article for author's affiliation.

For more than twenty years, the leaders of our profession, with the support of the Medical Library Association (MLA), have urged us to integrate research evidence into our practices. The title of the first MLA research policy, Using Scientific Evidence to Inform Information Practice, from 1995 conveys the idea that health sciences librarians should apply research results when making decisions [1]. The most recent MLA research policy, The Research Imperative, echoes this research integration theme [2]. Its introduction states: "health information practitioners, just like their health care practitioner colleagues, use the best available evidence when making a decision." Meanwhile, the current MLA strategic plan urges us to "improve the quality of health information services through the use, creation, and application of evidence in daily practice and processes" [3].

MLA presidents have weighed in on the need for us to integrate research evidence in our practice since 1997. Past President Rachael K. Anderson, AHIP, FMLA, noted, "In addition to supporting the evidence-based information needs of health professionals, we librarians need to develop our own version of evidence-based practice" [4]. Since 1997, most MLA presidents similarly have called for the integration of research evidence into practice [5-18]. The content of the Journal of the Medical Library Association during this era reflects a sustained interest in research and application of evidence [19].

President Anderson's inaugural speech served as one of several catalysts for me to write a commentary in Hypothesis that speculated about of the possible contours of evidence-based librarianship (EBL) in practice [20]. During the five years that followed, I created and then taught an MLA continuing education course on EBL fifteen times, explored the possibilities of applying research evidence in practice [21], and attempted to envision how we would incorporate the levels of evidence into our own practices [22]. During what might be termed this first historical period, a number of other health sciences librarians similarly pursued efforts to clarify the principles and core elements of our own version of evidence-based practice (EBP) [23-27].
DOI: http://dx.doi.org/10.3163/1536-5050.104.4.017

Health sciences librarians were central to the creation of EBP in the health professions. The historical evidence indicates that these other health professions needed us for them to create EBP. As two examples, we were involved in developing certain sophisticated tools such as PubMed/MEDLINE and CINAHL for identifying and interpreting authoritative evidence for making decisions [28]. The health professions nevertheless had so many more individuals within their ranks working on EBP, had so many more resources, utilized some of the same forms of evidence, and spoke the same language as health sciences librarians that we took much of our inspiration from their advances.

Early on, many noted the lack of rigorous evidence to support our decisions, and this realization prompted a second historical period of what came to be known as the evidence-based library and information practice (EBLIP) movement. From about 2004 until 2011, most professionals involved in EBLIP agreed that a lack of researchbased evidence posed the greatest barrier to that integration [29-33].

EBLIP proponents addressed this need by encouraging development of the body of researchbased evidence to serve the profession, while forming the channels to disseminate that evidence. In the United States, the Journal of the Medical Library Association and the Research Section's journal Hypothesis focused on producing evidence appropriate for librarians to make informed decisions [34]. EBLIP advocates in 2006 founded the international open access, peer-reviewed journal Evidence Based Library and Information Practice explicitly to disseminate the needed evidence to all types of information professionals. Beginning in 2001, biannual international "Evidence Based Library and Information Practice" conferences addressed building an evidence base. In 2008, MLA conducted the first of two delphi studies to identify the most important research questions facing the profession [35]. The second delphi study [36] prompted formation of fifteen teams to conduct systematic reviews to synthesize the best evidence on the highest-ranked research priorities [37]. These 
systematic reviews are designed to facilitate the dissemination of existing research. While much more rigorous evidence remains to be generated through research, the current systematic reviews project [38] and the aforementioned efforts suggest that we have far more evidence than previously believed on which to base our decisions.

The central question that forecasts what now appears to be an emerging third historical period in EBLIP might be phrased: Why do so many in our profession continue to not integrate research evidence in their practices? Stated another way: After so many years of both high-level MLA policy directions and numerous direct efforts within our ranks, what continue to be the persistent barriers to our colleagues engaging in EBP?

\section{THE NEW CHALLENGE}

These barriers to librarians integrating appropriate research-based evidence are not well understood. Because all other health professions rely on health sciences librarians to provide the evidence for their own practices, these barriers must be overcome to optimize the flow of evidence to ultimately benefit our users. On a more theory-based level of interpretation, we might observe that the diffusion of the EBP innovation [39] in health sciences librarianship seems far slower than might be expected.

Researchers have now begun to investigate why the greater availability of research evidence alone does not result in the integration of this evidence in practice. Booth analyzed 55 articles that posited at least 1 barrier to implementing EBLIP. Booth identified 9 themes that revolved around issues such as a lack of time, an absence of organizational support, a lack of a positive orientation toward research, and the need for training [40]. One Danish study explored this issue and pointed primarily to a lack of time among busy professionals [41]. The former editor of the journal Evidence Based Library and Information Practice used grounded theory

approaches with a purposeful sample of 19 academic librarians in Canada to identify barriers. The reported top 5 barriers were organizational inertia, a lack of time due to overwork, a lack of self-efficacy due to a lack of confidence or self-doubt, a lack of training on interpreting or conducting research, and a lack of usable information about available research [42]. Spring et al. conducted a focus group with 7 participants to create a survey completed by 316 health sciences librarians in the United Kingdom on research engagement [43]. While their study focused on practitioners who actually conduct research, the top-ranked barriers related to integrating research into practice were lack of research confidence and skills [44]. While these research endeavors inform our hypotheses about those barriers, the first 3 are limited by incorporating other types of librarians. Spring et al.'s study pertains to health sciences librarians, but in a health care system arguably distinct from ours in the United States.

These barriers have a potential downstream impact upon the health of all patients. Health sciences librarians play essential roles in ensuring that health care providers have the best evidence for optimal patient care [45-47]. Marshall et al. linked information provided by librarians at 118 hospitals to improved diagnosis, choice of appropriate medications, avoidance of adverse events, and appropriate advice given to patients [48]. An intervention involving clinical librarians changed $88 \%$ of clinicians' treatments of patients [49].

Health sciences librarians also serve vital roles in providing both the evidence and the training in EBP skills for all other health professions. Health sciences librarians train health professions students and trainees in EBP question formulation, searching, and some critical appraisal skills [50-52].

In the context of clinical decision making, health sciences librarians provide the essential EBP evidence. They further play key roles in creating systematic reviews that synthesize the best research evidence [53-57]. In recent years, health sciences librarians have been involved in the development and performance evaluations of point-of-care resources at patients' bedsides [58-61]. Health sciences librarians manage the sources of the research evidence in their electronic collections that are used both for training health professions students in EBP and that are integrated into EBP by health professions. In sum, health sciences librarians have been essential players in the flow of evidence to health professions for the downstream benefit of our patients. It logically follows that for health sciences librarians to advance EBP in other health professions, we need to utilize the best evidence in making our own decisions.

\section{WHAT NOW?}

The persistence of these barriers to integrating research results into practice does, admittedly, 
represent a discouraging setback. Yet, this setback represents only the most recent challenge to making EBLIP a reality in our profession. As an experienced researcher, I am determined to diagnose the situation and design solutions, but I need your help to organize my research strategies. Please reflect on these three key questions and then email me your answers:

1. To what extent do we, as a profession overall, practice EBLIP? Not at all? Somewhat? Most of the time?

2. What are the specific barriers to making EBLIP a reality?

3. For each barrier that you can identify, could you suggest at least one way to overcome that barrier?

\section{REFERENCES}

1. Dalrymple PW, Bastille JD, Bradley J, Dee CR, Humphreys BL, Marshall JG, Weller AC, Webb RE. Using scientific evidence to improve information practice. Chicago, IL: Medical Library Association; 1995.

2. Medical Library Association. The research imperative: the research policy statement of the Medical Library Association [Internet]. Chicago, IL: The Association; 2007 [cited 10 Mar 2016]. <http://www.mlanet.org/p/cm/ld/ fid $=541>$.

3. Medical Library Association. Strategic plan [Internet]. Chicago, IL: The Association; 2016 [cited 17 Mar 2016].

$<$ http://www.mlanet.org/p/cm/ld/fid=153>.

4. Anderson RK. Inaugural address, proceedings, ninetyseventh annual meeting, Medical Library Association, Inc., Seattle, Washington, May 24-28, 1997. Bull Med Libr Assoc. 1998 Jan;86(1):137-9. PubMed PMID: 16018060; PubMed Central PMCID: PMC226342.

5. Doyle JD. Inaugural address, proceedings, ninetyeighth annual meeting, Medical Library Association, Inc., Philadelphia, Pennsylvania, May 23-27, 1998. Bull Med Libr Assoc. 1999 Jan;87(1):136-9. PubMed PMID: 16018080; PubMed Central PMCID: PMC226549. 6. Weise FO. Inaugural address, proceedings, ninetyninth annual meeting, Medical Library Association, Inc., Chicago, Illinois, May 14-19, 1999. Bull Med Libr Assoc. 2000 Jan;88(1):97-132. PubMed PMID: 16018089; PubMed Central PMCID: PMC122099.

7. Homan JM. Inaugural address, proceedings, one hundredth annual meeting, Medical Library Association, Inc., Vancouver, British Columbia, Canada, May 5-11, 2000. Bull Med Libr Assoc. 2001 Jan;89(1):97-125. PubMed PMID: 16018091; PubMed Central PMCID: PMC31720.

8. Jenkins CG. Presidential address, proceedings, 102d annual meeting, Medical Library Association, Inc., Dallas,
Texas, May 17-23, 2002. J Med Libr Assoc. 2003 Jan;91(1): 106-12. PubMed PMID: 12568164; PubMed Central PMCID: PMC141200.

9. Watson L. Inaugural address, proceedings, $102 \mathrm{~d}$ annual meeting, Medical Library Association, Inc., Dallas, Texas, May 17-23, 2002. J Med Libr Assoc. 2003 Jan;91(1):127-32. PubMed PMID: 12568164; PubMed Central PMCID: PMC141200.

10. Thibodeau PL. Inaugural address, proceedings, 103rd annual meeting, Medical Library Association, Inc., San Diego, California, May 2-7, 2003. J Med Libr Assoc. 2004 Jan;92(1):134-8. PubMed PMID: 14762471; PubMed Central PMCID: PMC314120.

11. Marshall JG. Inaugural address, proceedings, 104th annual meeting, Medical Library Association, Inc., Washington, DC, May 21-26, 2004. J Med Libr Assoc. 2005 Jan;93(1):170-2. PubMed PMID: 17219703; PubMed Central PMCID: PMC545145.

12. Tooey MJ. Transforming ourselves, our profession, our association. MLA News. 2005 Apr;(375):18.

13. Shipman JP. Inaugural address, proceedings of the 106th annual meeting of the Medical Library Association. J Med Libr Assoc. 2007 Jan;95(1):e24-8. PubMed PMID: 17252057; PubMed Central PMCID: PMC1773029.

14. Funk ME. Presidential address, proceedings, 108th annual meeting, Medical Library Association, Inc., Chicago, IL, May 16-21, 2008. J Med Libr Assoc. 2009 Jan; 97(1):E2-5. DOI: http://dx.doi.org/10.3163/1559-9439.97.1. E1.

15. Holst R. Inaugural address, proceedings, 110th annual meeting of the Medical Library Association, Washington, DC, May 21-26, 2010. J Med Libr Assoc. 2011 Jan;99(1):

E16-9. DOI: http://dx.doi.org/10.3163/1536-5050.99.1.E1.

16. Blumenthal J. Inaugural address, proceedings, 112th annual meeting, Medical Library Association, Inc., Seattle, WA. J Med Libr Assoc. 2013 Jan;101(1):E12-5. DOI: http://dx.doi.org/10.3163/1536-5050.101.1.E1. PubMed PMID: 23405050; PubMed Central PMCID: PMC3543133.

17. Jones DA. Building our information future, building MLA's future: presidential priorities for 2013/14. MLA News. 2013 Apr;53(4):1, 11.

18. Kraft MM. Inaugural address, proceedings, 115th annual meeting, Medical Library Association, Inc., Austin, TX. J Med Libr Assoc. 2016 Jan;104(1):E1-33. DOI: http://dx.doi.org/10.3163/1536-5050.103.1.E1. PubMed PMID: 26807062; PubMed Central PMCID: PMC4722659. 19. Marshall JG. Linking research to practice: the rise of evidence-based health sciences librarianship. J Med Libr Assoc. 2014 Jan;102(1):14-21. DOI: http://dx.doi.org/10. 3163/1536-5050.102.1.005. PubMed PMID: 24415915; PubMed Central PMCID: PMC3878930.

20. Eldredge J. Evidence based librarianship. Hypothesis [Internet]. 1997 Fall;11(3):4-7 [cited 11 Jan 2016]. <http:// www. $\mathrm{mlanet} . \mathrm{org} / \mathrm{p} / \mathrm{cm} / \mathrm{ld} / \mathrm{fid}=737 \& \mathrm{tid}=511 \&$ sid $=647>$. 
21. Eldredge JD. Evidence-based librarianship: an overview. Bull Med Libr Assoc. 2000 Oct;88(4):289-302. PubMed PMID: 11055296; PubMed Central PMCID: PMC35250.

22. Eldredge JD. Evidence-based librarianship: levels of evidence. Hypothesis [Internet]. 2002 Fall;16(3):10-3 [cited 11 Jan 2016]. < http://www.mlanet.org/p/cm/ld/ fid $=737 \&$ tid $=511 \&$ sid $=647>$.

23. Booth A. Evidence-based librarianship: one small step. Health Inf Libr J. 2002 Jun;19(2):116-9. PubMed PMID: 12389610 .

24. Crumley E. Reflections on the evidence-based librarianship conference. Bibliotheca Medica Canadiana. 2001;23(2):55.

25. Koufogiannakis D, Crumley E. Evidence-based librarianship. Feliciter 2002;48(3):112-4.

26. Booth A. Bridging the research-practice gap? the role of evidence based librarianship. New Rev Inf Libr Res. 2003 Dec;(1):3-23.

27. Brice A, Booth A. Consider the evidence. Libr Inf Update. 2004 Jun;3(6):32-3.

28. Eldredge JD. Evidence-based practice. In: Wood S, ed. Introduction to health sciences librarianship.

Binghamton, NY: Haworth Press; 2008. p. 245-69.

29. Grefsheim SF, Rankin JA, Perry GJ, McKibbon KA. Affirming our commitment to research: the Medical Library Association's research policy statement: the process and findings. J Med Libr Assoc. 2008 Apr;96(2): 114-20. DOI: http://dx.doi.org/10.3163/1536-5050.96.2. 114. PubMed PMID: 18379666; PubMed Central PMCID: PMC2268236.

30. Crumley E, Koufogiannakis D. Developing evidencebased librarianship: practical steps for implementation. Health Inf Libr J. 2002 Jun;19(2):61-70.

31. Bexon N, Brice A, Booth A. Using research in practice. Health Inf Libr J. 2003 Dec;20(4):240-3.

32. Booth A, Brice A, eds. Evidence-based practice for information professionals. London, UK: Facet; 2004. 33. Rossall H, Boyes C, Montacute K, Doherty P. Developing research capacity in health librarians: a review of the evidence. Health Inf Libr J. 2008 Sep;25(3): $159-74$.

34. Plutchak TS. Building a body of evidence. J Med Libr Assoc. 2005 Apr;93(2):193-5. PubMed PMID: 15858620; PubMed Central PMCID: PMC1082934.

35. Eldredge JD, Harris MR, Ascher MT. Defining the Medical Library Association research agenda:

methodology and final results from a consensus process. J Med Libr Assoc. 2009 Jul;97(3):178-85. DOI: http://dx.doi. org/10.3163/1536-5050.97.3.006. PubMed PMID:

19626143; PubMed Central PMCID: PMC2706444.

36. Eldredge JD, Ascher MT, Holmes HN, Harris MR. The new Medical Library Association research agenda: final results from a three-phase delphi study. J Med Libr Assoc. 2012 Jul;100(3):214-8. DOI: http://dx.doi.org/10.3163/
1536-5050.100.3.012. PubMed PMID: 22879811; PubMed Central PMCID: PMC3411260.

37. Eldredge JD, Holmes HN, Ascher MT. Moving the EBLIP community's research agenda forward. Evidence Based Libr Inf Pract. 2015;10(2):170-3. (Available from: $<$ https://ejournals.library.ualberta.ca/index.php/EBLIP/ article/view/24336/18434>. [cited 9 Mar 2016]). 38. Eldredge JD, Ascher MT, Holmes HN. An innovative model of evidence-based practice for other professions. J Med Libr Assoc. 2015 Apr;103(2):100-2. DOI: http://dx. doi.org/10.3163/1536-5050.103.2.009. PubMed PMID: 25918491; PubMed Central PMCID: PMC4404847. 39. Rogers EM. Diffusion of innovations. 4th ed. New York, NY: The Free Press; 2003.

40. Booth A. Barriers and facilitators to evidence-based library and information practice: an international perspective. Perspectives Int Libr. 2011 May; 1:1-15. 41. Johannsen CG. Evidence-based practice in librariesprinciples and discussions. Libri. 2012;62:174-84.

42. Koufogiannakis D. Determinants of evidence use in academic librarian decision making. Coll Res Libr. 2015 Jan;76(1):100-14.

43. Spring H, Doherty P, Boyes C, Wilshaw K. Research engagement in health librarianship: outcomes of a focus group. Libr Inf Sci Res. 2014 Oct;36(3/4):142-53.

44. Spring $\mathrm{H}$. An investigation into the barriers to and priorities for research engagement in health librarianship. Int J Health Inf Manage Res. 2014 Apr;2(1):58-79.

45. Li P, Wu L. Supporting evidence-based medicine: a survey of U.S. medical librarians. Med Ref Serv Q. 2011; 30(4):365-81. DOI: http://dx.doi.org/10.1080/02763869.

2011.609069. PubMed PMID: 22040243.

46. Cogdill KW, Ambriz L, Billman BL, Carter KV, NailChiwetalu B, Trumble JM, El-Khayat YM, Nuñez AV. The Frontera Collaboration: a preliminary report of health sciences librarians promoting evidence-based practice in U.S.-Mexico border communities. Med Ref Serv Q. 2012; 31(4):400-13. DOI: http://dx.doi.org/10.1080/02763869. 2012.724285. PubMed PMID: 23092417; PubMed Central PMCID: PMC3481169.

47. Aldrich AM, Schulte SJ. Establishing a new clinical informationist role in an academic health sciences center. Med Ref Serv Q. 2014;33(2):136-46. DOI: http://dx.doi. org/10.1080/02763869.2014.897511. PubMed PMID: 24735263.

48. Marshall JG, Sollenberger J, Easterby-Gannett S, Morgan LK, Klem ML, Cavanaugh SK, Oliver KB, Thompson CA, Romanosky N, Hunter S. The value of library and information services in patient care: results of a multisite study. J Med Libr Assoc. 2013 Jan;101(1):38-46. DOI: http://dx.doi.org/10.3163/1536-5050.101.1.007. PubMed PMID: 23418404; PubMed Central PMCID: PMC3543128.

49. Aitken EM, Powelson SE, Reaume RD, Ghali WA. Involving clinical librarians at the point of care: results of 
a controlled intervention. Acad Med. 2011 Dec;86(12): 1508-12. DOI: http://dx.doi.org/10.1097/ACM. 0b013e31823595cd. PubMed PMID: 22030761.

50. Tennant MR, Edwards M, Miyamoto MM. Use of instructional design theory and an individualized hybrid strategy for assessment in library-based instruction. J Med Libr Assoc. 2012 Oct;100(4):319-22. DOI: http://dx. doi.org/10.3163/1536-5050.100.4.018. PubMed PMID: 23133336; PubMed Central PMCID: PMC3484947.

51. Kean EB. Assessment and impact of a new role as an embedded librarian in nursing online journal clubs. J Med Libr Assoc. 2013 Oct;101(4):335-8. DOI: http://dx.doi.org/ 10.3163/1536-5050.101.4.018. PubMed PMID: 24163608; PubMed Central PMCID: PMC3794692.

52. Blanco MA, Capello CF, Dorsch JL, Perry GJ, Zanetti ML. A survey study of evidence-based medicine training in US and Canadian medical schools. J Med Libr Assoc. 2014 Jul;102(3):160-8. DOI: http://dx.doi.org/10.3163/ 1536-5050.102.3.005. PubMed PMID: 25031556; PubMed Central PMCID: PMC4076124.

53. Murphy SA, Boden C. Benchmarking participation of Canadian university health sciences librarians in systematic reviews. J Med Libr Assoc. 2015 Apr;103(2): 73-8. DOI: http://dx.doi.org/10.3163/1536-5050.103.2.003. PubMed PMID: 25918485; PubMed Central PMCID: PMC4404858.

54. Golder S, Loke YK, Zorzela L. Comparison of search strategies in systematic reviews of adverse effects to other systematic reviews. Health Inf Libr J. 2014 Jun;31(2):92105. DOI: http://dx.doi.org/10.1111/hir.12041. Epub 2014 Apr 23. PubMed PMID: 24754741.

55. Harris MR. The librarian's roles in the systematic review process: a case study. J Med Libr Assoc. 2005 Jan; 93(1):81-7. PubMed PMID: 15685279; PubMed Central PMCID: PMC545126.

56. Rethlefsen ML, Farrell AM, Osterhaus Trzasko LC, Brigham TJ. Librarian co-authors correlated with higher quality reported search strategies in general internal medicine systematic reviews. J Clin Epidemiol. 2015 Jun; 68(6):617-26. DOI: http://dx.doi.org/10.1016/j.jclinepi. 2014.11.025. Epub 2015 Feb 7. PubMed PMID: 25766056.
57. Koffel JB. Use of recommended search strategies in systematic reviews and the impact of librarian involvement: a cross-sectional survey of recent authors. PLOS One. 2015 May 4;10(5):e0125931. DOI: http://dx.doi. org/10.1371/journal.pone.0125931. eCollection 2015. PubMed PMID: 25938454; PubMed Central PMCID: PMC4418838.

58. Kronenfeld MR, Bay RC, Coombs W. Survey of user preferences from a comparative trial of UpToDate and ClinicalKey. J Med Libr Assoc. 2013 Apr;101(2):151-4. DOI: http://dx.doi.org/10.3163/1536-5050.101.2.011. PubMed PMID: 23646031; PubMed Central PMCID: PMC3634379.

59. Farrell A. An evaluation of the five most used evidence based bedside information tools in Canadian health libraries. Evidence Based Libr Inf Pract. 2008;3(2): 3-17.

60. Eldredge JD, Hall LJ, McElfresh KR, Warner TD,

Stromberg TL, Trost J, Jelinek DA. Rural providers' access to online resources: a randomized controlled trial. J Med Libr Assoc. 2016 Jan;104(1):33-41. DOI: http://dx.doi.org/ 10.3163/1536-5050.104.1.005. PubMed PMID: 26807050;

PubMed Central PMCID: PMC4722640.

61. Maggio LA, ten Cate O, Moorhead LL, van Stiphout F, Kramer BMR, ter Braak E, Posley K, Irby D, O'Brien BC. Characterizing physicians' information needs at the point of care. Perspect Med Educ. 2014 Nov;3(5):332-42. DOI: http://dx.doi.org/10.1007/s40037-014-0118-z. PubMed PMID: 24865885; PubMed Central PMCID: PMC4235804.

\section{AUTHOR'S AFFILIATION}

Jonathan D. Eldredge, MLS, PhD, AHIP, jeldredge@ salud.unm.edu, Associate Professor, School of Medicine, and Evidence Based and Translational Sciences Collaboration Coordinator, Biomedical Informatics Research, Training and Scholarship, Health Sciences Library and Informatics Center, University of New Mexico, Albuquerque, NM 87131-0001 